\title{
Scribe's Column
}

\section{Whatever Else It Is-It Still Isn't Cricket}

Readers of these columns may recall that some years ago we scooped the psychiatric world with an exclusive article on the 1974 reorganization of the National Cricket Service and its effects on a local hospital cricket team. At that time Captains of such teams were abolished and replaced by Multidisciplinary Cricket Management Consensus decision-making processes: ongoing as I recall.

This centrally dictated change was reinforced at a local level by the much dreaded Cricket Advisory Service: a sort of cross between the Commissioners for the Dissolution of Monasteries and the Inquisition. The Inquisitors, while not always knowing much about cricket, made good this deficiency by stern dogma ex cathedra. Recalcitrant and non-penitent cricketers were handed over to the secular arm for such tortures as management courses and other forms of auto-da-fé.

The multidisciplinary team therefore met with great frequency and varying degrees of enthusiasm, those who knew least about the subject under discussion being the most enthusiastic. Despite all this (some said because of it) the standard of cricket sadly declined, in some cases vanishing altogether. Not only did the teams not notice this but some of them formed the impression that the game was going more smoothly than ever.

We were all on first name terms: and none of that nonsense about how 'we're all on first name terms on this ship and my first name's Captain.' Identifying uniform vanished. Informal dress became de rigueur, though one didn't always think that senior nurses, or nurse persons, looked at their most attractive in sneakers, dirty tight jeans and a rugger jersey.

All good things come to an end. Word eventually reached the National Cricket Service Headquarters itself of certain deficiencies. For example, there weren't even enough cricket balls to go round despite HQs impression-and everyone else's too-that they'd made more than enough: they came to what seemed to them (but to nobody else) the inescapable conclusion that what was needed was more reorganization.

This time they called in not the Cricket Advisory Service, but as far as our hospital cricket team was concerned, the manager of a local supermarket. (Not the one that piles them high and sells them cheap but a more upmarket one where elegant North Yorkshire displaced Sloane Rangers can be seen tiptoeing out with just one fairly wild mallard and a bottle of own brand claret.)

Fortified, not by claret but by an absolute conviction in management methods, and although entirely lacking any knowledge of cricket, our manager set out to revitalize our team. As an immediate step he called for more managers.

News of this having reached other hospital teams, the more awake of them swiftly appointed one of their own junta as manager: forestalling any alien influences. The pattern varied. Some teams nominated the Treasurer as Captain: though it was somewhat unfortunate that at least one of these felt so constrained by recently imposed financial cuts that he reduced the size of the cricket team from eleven to six.

Some teams thought of those senior nurses who in olden times stood patiently on the boundary complete with first aid kits: but they had changed out of all recognition and were now incoherently preoccupied with the democratic cricket first aid process in the ongoing outfield situation. Some thought of their kindly old team doctors who had given such valuable service over the years but who weren't quite clear in their minds as to whether they were administrators or cricketers.

So for the most part the Captaincy went to the erstwhile Team Secretary: not only because he was quite literate but also because, in drawing up fixture lists over the years, he had come into contact with other human beings.

These arrangements by no means satisfied National Cricket Service Headquarters. Captains not only of Cricket but of Industry were what they wanted and that was what they were going to get with, as they put it, a firm smack of authority.

So they put the thumbscrews on the shortlists and reserved the final decision. As they were sensitive about the allegation that many of the newly appointed Captains were merely being paid more for what they had previously done for less, the obvious answer was to appoint someone with no experience of cricket and pay them twice as much. The National Cricket Service had after all its own career and political structure to think about and it was understandable that people should want to make a name for themselves. In that they were eminently successful.

What has been less successful has been the effect of all this upon our local hospital cricket team (at, of course, grass roots level-though frankly the outfield hasn't been cut for months: no mower).

We were initially impressed by the dynamic and tycoon-like performance of our new Captain of Industry (though it had admittedly been a small one and selling secondhand cars isn't everyone's cup of tea). He cut discussion (and consultation) to a merciful minimum and got on with playing the game even though he wasn't too certain of the rules.

In our first match we strode on to the field through the long grass in a state of pleasurable anticipation. Admittedly our flannels were off-white, if not indeed frankly dirty: but this was because the laundry had gone out to tender, and so it was nobody's fault. It was also true that the preparation of the wicket, like the cleaning of the pavilion, left much to be desired, and we were impressed by the way in which our Captain said he would make immediate representations to the contract cleaning firm responsible, as soon as he had found out who they were.

We felt sorry when our Captain, having won the toss and put the other side in to bat, experienced obvious difficulties in the 
intricacies of placing the field. It was unfortunate whenpresumably under the impression that the man was a fielder-he directed the square leg umpire to position himself at silly mid off. I will pass over the umpire's comments, though he seemed to think he was back in a multidisciplinary situation and as a boiler man with strong union affiliations he clearly wasn't to let it pass unchallenged.

We ran into other difficulties. When we tried to order some cricket bats we discovered that because of expense the Service Headquarters had only two varieties-one too small and the other too large. They had called in expert cricketers to advise about this but the experts were unable to consult with us because they said they were bound by the Official Cricket Secrets Act.

The worst blow of all came when the umpire said play. We discovered we had no balls and in a way we felt emasculated. Our Captain said he would take this matter up as soon as possible and he led us off the field.

Our spirits, if nothing else, were restored by a somewhat lengthy speech which he made. Some of us were moved to tears. Because, as he said, he came as a new boy he was able to approach everything with a completely open mind. ('Open mouth' said the square leg umpire.)

What he had learnt, he said, in his business life was to put the customer first. Now it was a matter of putting the Patient Spectators first, for that, he said, was what the hospital cricket team was there for.

He said he had noticed that there weren't as many Patient Spectators as he had hoped to see. We had to break it gently to him that the wise counsels of the National Cricket Service had urged as many such people as possible to leave the hospital cricket grounds and instead to seek the comforts and benefits of the local public parks where they could be seen all day sitting on the benches under the impression that it was something to do with community cricket.

Once again: Who's for Tennis?

\section{The College}

\section{Natalie Cobbing Travelling Fellowship (Psychiatry of Mental Handicap)}

A Fellowship (value $£ 2,000$ ) will be awarded every two years by the Royal College of Psychiatrists to further the training of specialists in this branch of psychiatry by enabling them to extend their experience with travel to appropriate centres overseas.

Applicants must submit an account of their previous experience in this field and a reasoned account of their training needs and how the specialty might benefit from their use of the Fellowship. They must also submit evidence in the form of published or unpublished work that they would be an appropriate recipient of the Fellowship.

1. All applicants must possess the MRCPsych.

2. All applicants must be working in the United Kingdom or Republic of Ireland.

3. Applicants, who must be under the age of 40 , may be of senior registrar or consultant status within three years of appointment.
4. Applicants must submit: (i) a curriculum vitae; (ii) the names of two referees; (iii) a proposal as to how they might spend their time, with confirmation, if possible, from their host centre(s) abroad; (iv) an account of original research, published or unpublished papers or reviews in the field of mental handicap or psychiatry. In the case of joint research, the exact contribution of each author must be made clear.

5. Successful candidates will be expected to submit a short report to the College on their use of the Fellowship.

6. The awards will be made by a panel consisting of the Dean and two assessors nominated by the President and Chairman of the Mental Handicap Section respectively.

7. In the event of none of the applications being of a satisfactory standard, no award will be made.

8. Applications submitted after 31 March will be taken as applications for the following Fellowship.

\section{Categories of Approval for Training Schemes}

The Court of Electors has accepted the recommendation of the Central Approval Panel that the Approval Categories for rating training schemes should be changed to correspond to those employed by the Joint Committee on Higher Psychiatric Training. The ' $A$ ' and ' $P$ ' categories have done their work as carrots and sticks, and very valuable they have been. But they have been misunderstood and some ' $A$ ' schemes have rested too long on their laurels and ' $P$ ' schemes have felt hard done by when they were already improving. The categories were rather inflexible.

In future, schemes will be either 'Unapproved' or
'Approved'. If 'Unapproved', mandatory requirements may be made which must be met before approval can be given. If 'Approved', the duration of training will be given as some schemes can only provide training for a limited period of time. Then the interval before the next visit will be given, which will vary from six months to up to four years and certain recommendations made, some of which will be mandatory and others desirable, but not essential.

We believe that this system is more appropriate for the present stage of development of training schemes.

J. L. T. Birley Dean 